\title{
FROM GUEST-WORKERS TO SETTLERS
}

\section{The Representation and Agency of Sweden-Finnish Immigrants in Theatre, 1970-1975}

\author{
Mikko-Olavi Seppälä \\ Docent, University of Helsinki
}

As migration continues to shape the modern world and migrant literature gains attention in the West, this article picks up a historical case and turning point in northern Europe in the early 1970s. Focusing on theatre and plays on Finnish migration to Sweden, this article discusses how the issues regarding Sweden-Finnish migrants' agency and representation became politicised, problematised and reworked in the beginning of the 1970s. The aim is to trace and consider larger ideological and minority political shifts in the understanding of migration and the debate on the agency and the cultural needs of SwedenFinnish migrant workers.

The empirical material of the article consists of play manuscripts, the archives of the National Association of Finns in Sweden ${ }^{1}$ (RSKL) and the main newspapers of Sweden-
Finns (Ruotsinsuomalainen) and in Finland (Helsingin Sanomat).

While Finnish migration to and immigrants in Sweden have been studied a great deal, the theatrical activity by and for immigrants remains to be under-researched. ${ }^{2}$ Sweden-Finnish literature, however, has been researched by Satu Gröndahl, Eila Rantonen, Marja-Leena Pynnönen and Erkki Vallenius. While Pynnönen and Vallenius mapped the field and analysed the typical themes, ${ }^{3}$ Rantonen and Gröndahl have studied SwedenFinnish literature in the wider contexts of migrant and working-class literature. ${ }^{4}$ Gröndahl has remarked how migrant literature is traditionally linked with the question of the representativeness of a minority: "the works are understood within an 'ethnic' context that is liable to exclude wider interpretations." It is

1 The name of the RSKL was originally the Central Association of Finnish Societies in Sweden.

2 For overviews, see Laila Lehén-Astala, "Suomenkielinen teatteri Ruotsissa," in Suomen kieli Ruotsissa, ed. Sulo Huovinen (Stockholm: Finn-kirja, 1980); Maijaliisa Jokinen, "Sverigefinska kultursträvanden," in Finnarnas historia i Sverige, vol. 3, Tid efter 1945, ed. Jarmo Lainio (Jyväskylä: Finnish Historical Society \& Nordiska Museet, 1996); Jouni Korkiasaari, "Suomalaiset Ruotsissa 1940-luvulta 2000-luvulle," in Suomalaiset Ruotsissa, by Jouni Korkiasaari \& Kari Tarkiainen (Turku: Siirtolaisuusinstituutti, 2000).

3 Marja-Liisa Pynnönen, Siirtolaisuuden vanavedessä: Tutkimus ruotsinsuomalaisen kirjallisuuden kentästä vuosina 1956-1988 (Helsinki: SKS, 1988); Erkki Vallenius, Kansankodin kuokkavieraat: II maailmansodan jälkeen Ruotsiin muuttaneet suomalaiset kaunokirjallisuuden kuvaamina (Helsinki: SKS, 1998).

4 Eila Rantonen, "Maahanmuuttajat ja kirjallisuus Suomessa ja Ruotsissa," in Vähemmistöt ja monikulttuurisuus kirjallisuudessa, ed. Eila Rantonen (Tampere: Tampere University Press, 2010); Satu Gröndahl, "Sweden-Finnish Literature: Generational and Cultural Changes," in Migrants and Literature in Finland and Sweden, eds. Satu Gröndahl \& Eila Rantonen (Helsinki: SKS, 2018).

5 Satu Gröndahl, "Sweden-Finnish Literature," 53. 
evident that the question of representativeness turned out to be critical in the reception of the Sweden-Finnish migrant plays.

The mediatised representations - social reports, television and radio reportages, pamphlets and novels - depicting Finnish migrant workers in Sweden became popular in Finland at the turn of the 1970s. Journalists visited mine workers or went to work at factories in order to collect material and interview workers. ${ }^{6}$ In the popular consciousness, the Stockholm harbour area Slussen became notorious for its Finnish drink and drug addicts, "the Slussen rangers" (Slussenin sissit). The stereotype was reinforced in popular entertainment. ${ }^{7}$

It must be stressed that literature depicting Finnish migrants in Sweden from the late 1960s and early 1970s was largely created and published in Finland for the popular demand of Finnish-speaking audiences mainly in Finland. It can be coined as Sweden-Finnish migrant literature because of its themes. Finnish publishing houses actively searched for manuscripts on the topic. Hannu Ylitalo, who was to become the leading novelist among Sweden-Finns, was a teacher of Finnish language in Sweden. Having been asked by a Finnish publisher to write a migrant novel, he went to work at a car factory in order to trace migrant workers' experiences. His realist novel Saatanan suomalainen ("Fucking Finn", 1971) became a success and was translated into Swedish and Russian and was followed by two other novels. According to Pynnönen, the grim and pessimistic tone of the novel aligned well with the Finnish authorities' efforts to restrain emigration. Controversial and yet influential among the Sweden-Finns, the novel depicted migrants as class-conscious workers and their children as tormented outsiders. ${ }^{8}$

It should be noted that in Ylitalo's novel, Finnish migrant workers are seen as "humble and obedient labour reserve" of global capitalism in a similar way as they are regarded in the three plays analysed here, which were written immediately after the novel. In Ylitalo's book, however, the very character who contextualises Finns in this way is actually a Swedish communist, Börje. From his Marxist anticapitalist position, Börje prophesies that large flocks of labour will wander like lemmings all over Europe from one country to another. Ylitalo's novel also stresses the cultural needs of Finnish migrants and claims that there is a full house every time when a theatre company from Finland comes to perform. ${ }^{9}$

Migration turned out to be a topical theme in the Finnish theatre as well. I will take a closer look at the theatrical representation of Finnish migration to Sweden and discuss three notable Finnish plays with migrant protagonists introduced in 1971-1972, namely Yrjö Nipanen (1971) by Lauri Sipari, Matti Väkevä (1972) by Jussi Kylätasku, and Ku Ite-Romppanen Ruobtiin läksi ja perreensäki vei (1972) by Pekka Lounela. As I am merely interested in looking at how migration was framed and interpreted in the plays and what kind of migrant characters were created, I will not analyse the plays in detail. How did the plays contribute to and mirror the ongoing discussions on migration, assimilation and integration? Why did they rouse critical opinions and controversy among Sweden-Finnish au-

6 Books include Esko Tommola, Suomalaisia Ruotsissa (1969); Heikki Kekkonen \& Erkki Lepokorpi, Hatkat (1969); Sara Lidman, Kaivos (1970); Heikki Kekkonen, Ruotsin priha (1971); Margareta Keskitalo, Liukuhihnaballadi (1971); Toivo Kareketo, Reijo Ventola, ruotsinsuomalainen (1971). Pynnönen, Siirtolaisuuden vanavedessä, 66-67.

7 E.g. Juha Vainio's comic song "Slussenin sissit" (1968) and Aarre Haunia's crime novel Slussenin sissit (1974).

8 Pynnönen, Siirtolaisuuden vanavedessä, 67-69.

9 Hannu Ylitalo, Saatanan suomalainen (Helsinki: Kirjayhtymä, 1971), 147, 187; On theatre, see also Osmo Hormia et al., Ruotsin suomalaiset: Nykyhetki ja tulevaisuus (Porvoo \& Helsinki: WSOY, 1972), 95. 
diences? After that, I will take a closer look at how Sweden-Finnish communities and advocacy organisations started to support migrants' own creations based on their own experiences.

Before considering these questions, I will first provide a wider context of Finnish migration to Sweden and a description of the cultural activities among the Sweden-Finnish settlement.

\section{Economic integration and Finnish migrant workers in Sweden}

The two neighbouring countries, Sweden and Finland, had close historical ties even if the Finnish and Swedish languages differ significantly. As the Swedish-speaking minority in Finland was protected by the bilingual constitution from the 1920s, the Finnish-speaking minority in Sweden was forced to assimilate. After the Second World War, the industrialised Sweden absorbed Finnish manual workers who were looking for higher wages and better social security.

This was part of a larger post-war development. Several Western European countries recruited foreign 'guest-workers' who contributed as low-skilled and low-wage labour to the expanding industrial mass production. $\mathrm{Mi}$ grant manual workers were regarded as temporary labour units, which could be utilised and then sent away. The prevalent policy was to leave them without social security, citizenship and political rights. The migrants' permanent settlement and the entry of their family members were discouraged. In, for example, West Germany, the number of foreign workers grew from 95,000 in 1956 to 1.3 million in 1966 and to 2.6 million in $1973 .{ }^{10}$

As one of the most industrialised countries in Europe, Sweden's mining, metal and textile industries as well as the service sector had a high demand for unskilled workers. Sweden turned to Finland and southern Europe to recruit young workers. From the 1950s onwards, Finns constituted the largest group of foreign workers in Sweden. The devaluation in the Swedish krona in 1967 increased wages by $30 \%$ and tempted young people from underemployed and often underdeveloped rural regions to migrate to the higher-wage economy. The mass migration to Sweden led to the regulation of work and residence permits in 1968 which cut the influx of Southern and non-European immigrants. ${ }^{11}$

However, Finnish citizens were not affected by the new regulations as the Nordic countries (Denmark, Finland, Iceland, Norway and Sweden) had agreed on a common labour market already in 1954 in order to encourage cultural and social interaction and economic cooperation. This meant that for Finnish citizens, there was no need for residence and work permits in Sweden. Finnish migration to Sweden peaked in 1969 and 1970 with ca 40,000 people migrating to Sweden annually and causing a decline in the country's population. The majority of the immigrants came from the underdeveloped rural northern Finland whose small farms had suffered as a result of the mechanisation of the local forest industry. ${ }^{12}$

The mass migration from Finland to Swe-

10 Stephen Castles, Hein De Haas \& Mark J. Miller, The Age of Migration: International Population Movements in the Modern World, 5th ed. (London: Palgrave Macmillan, 2014), 106-107.

11 Kirk Scott, The Immigrant Experience: Changing Employment and Income Patterns in Sweden, 1970-1993 (Lund: Lund University Press, 1999), 3-4, 38-40; Vilho A. Koiranen, Suomalaisten siirtolaisten sulautuminen Ruotsissa: Sosiologinen tutkimus Ruotsiin vuosina 1945-1959 muuttaneiden suomenkielisten siirtolaisten kulttuurin muuttumisesta (Porvoo \& Helsinki: WSOY, 1966), 86-87.

12 Jouni Korkiasaari, "Suomalaiset Ruotsissa," 146, 156-158; Scott, Immigrant Experience, 37-40; Riitta Hjerppe, Kasvun vuosisata (Helsinki: VAPK, 1990), 48-58. 


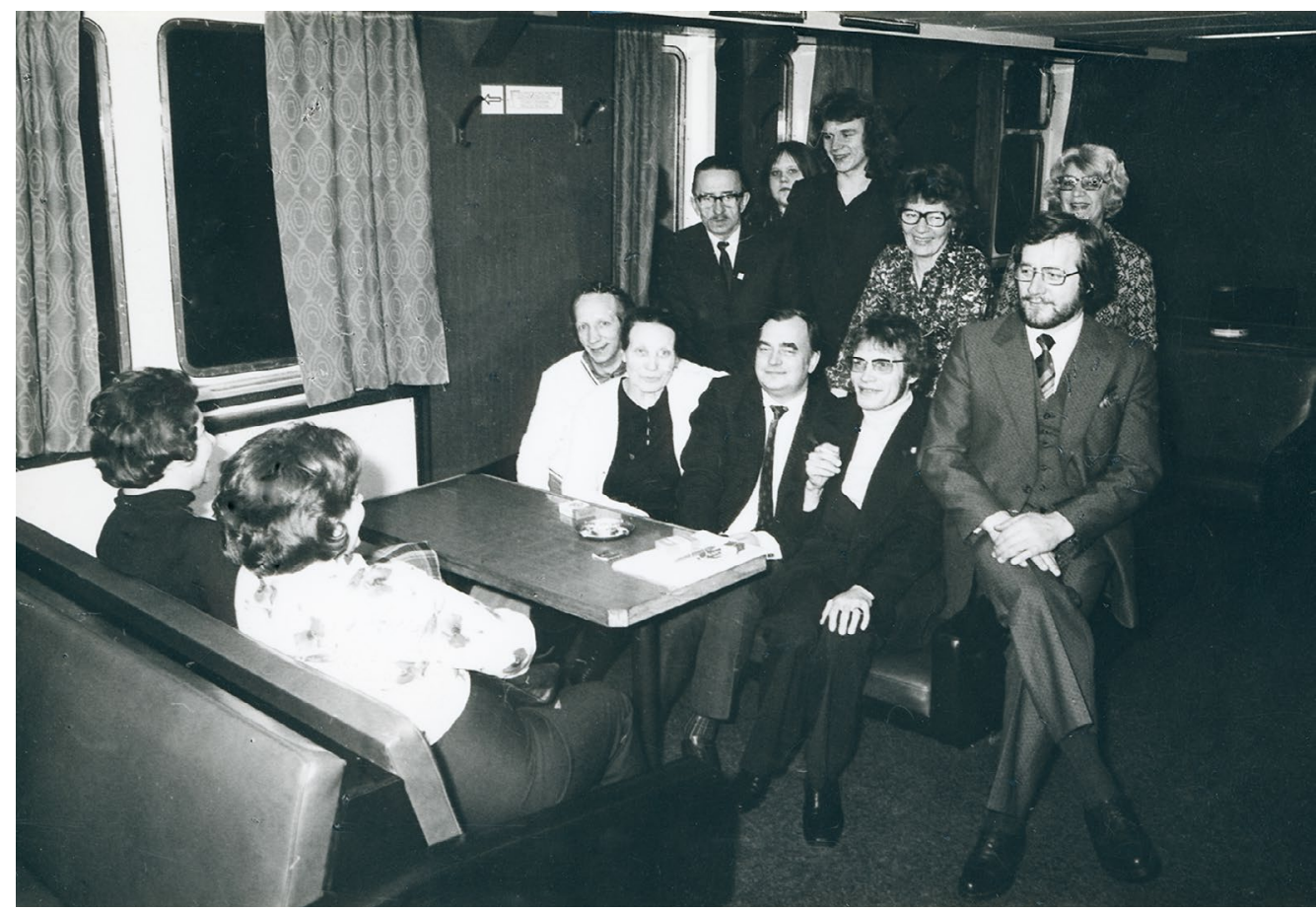

The author Pekka Lounela (in the middle) joined the Ykspihlaja Workers' Theatre in the Swedish tour of his play in 1974. Photo: Theatre Museum, Finland.

den coincided with the 1968-1970 NORDEK plan of expanding Nordic cooperation from the common labour market to a customs union and an economic community. At the same time, the prolonged question of opening the membership of the European Economic Community (EEC) to the UK, Ireland, Denmark and Norway remained unanswered. The western countries outside the EEC had established the European Free Trade Association (EFTA) in 1960. Aspiring to a Western orientation whilst being under pressure from the Soviet Union, even Finland became an associate member of the EFTA in 1961.

The 1968-1970 NORDEK plan was supported by the Nordic social democrat governments. As NORDEK was supposed to pave the way for the future EEC memberships, it was objected by the Soviet Union which pres- sured Finland to abjure the agreement in 1970. In 1972, Denmark decided to join the EEC whereas in Norway a referendum rejected the membership agreement and forced the government to resign.

As the 1973 oil crisis led to global recession, the rapid growth of the Swedish economy halted. ${ }^{13}$ Even before that, the Finnish authorities had tried to encourage migrants to return to Finland. In 1973, Finland and Sweden signed a mutual agreement on the channelling of the labour force between the two countries. From now on, the Swedish industry was not allowed to recruit workers in Finland. However, it turned out to be difficult to regulate migration with dictates. It has been estimated that, throughout the 1970 s and the beginning of the 1980s, there were over 100,000 Finnish citizens in the Swedish 
labour force. The permanent settler numbers amount to some 250,000 people. $^{14}$

In the course of the 1970s, Sweden adopted progressive immigrant policies stressing the pluralist and multicultural nature of Swedish society. Immigrant participation in Swedish society and minorities' access to cultural services in their mother tongue was supported.

\section{Theatre among \\ Sweden-Finnish migrants}

The Central Association of Finnish Societies in Sweden (RSKL) was founded in 1957. Since some of the Finnish immigrants would settle in Sweden and others return to Finland, the association had a twofold task in promoting the assimilation of Finns into Swedish society on the one hand and helping them to maintain their Finnishness on the other. In addition, the association sought to coordinate cultural work among the local societies and contribute to creating special SwedenFinnish traditions. ${ }^{15}$ Organised from the 1960 s onwards, the annual cultural festivals brought Sweden-Finns together to enjoy and rate amateur performances. The immigrants competed in several performance categories such as singing, poetry reading, sketches, and plays. At the beginning, there were strong ties between the RSKL and the nationalistic Association of Finnish Culture and Identity in Finland. Towards the end of the 1960s and during the 1970s, however, the RSKL's cooperation with the Swedish authorities, and labour and cultural organisations both in Finland and Sweden strengthened.

Although social dancing remained the most popular form of leisure activity among Sweden-Finns, theatre activities had a strategic cultural mission in their aim to support art education, community-building and the preservation of the Finnish language and culture. There were two main policies: on the one hand, cultural organisations strived to offer immigrants a chance to attend professional theatre performances in Finnish. On the other hand, the Sweden-Finnish societies were encouraged to develop their own amateur theatres with the help of professional instructors. The Finnish amateur activities would contribute to maintaining the mother tongue and supporting immigrant families' self-esteem. From the 1960s onwards, the RSKL coordinated the workshops together with the Workers' Educational Association in Sweden (ABF). Invited from Finland, the instructors and guest directors represented two national amateur theatre organisations (the agrarian SHTL and the socialist TNL). From 1969 onwards, several Sweden-Finnish amateur theatres even became members of these Finnish organisations and took part in festivals and workshops in Finland. ${ }^{16}$

As for professional theatre, there were several organisations involved in inviting and financing guest performances and tours from Finland to Sweden. In addition to its own touring companies, the National Touring Theatre of Sweden (Riksteatern, led by Hans Ullberg) organised and financed tours by other companies. Having invited the Swedish-speaking Lilla Teatern from Finland to perform already in 1960, Riksteatern started to import Finnish-speaking theatres for small tours in 1966. From 1970, Riksteatern imported annually two theatre productions from Finland. As touring required flexible productions and an easy-going attitude, most of the guest

14 Korkiasaari, "Suomalaiset Ruotsissa," 156, 174.

15 The annual report of the RSKL 1958-59, Coll. "Kirjeenvaihto ja asiakirjat 1957-1960", The Archive of the Central Association of Finnish Societies in Sweden, National Association of Finns in Sweden (RSKL), Stockholm.

16 Mikko-Olavi Seppälä, Parempi ihminen, parempi maailma: Suomalaisen työväenteatterin päättymätön tarina (Helsinki: Vastapaino, 2020), 297-303. 
performers were independent group theatres without permanent performance spaces. ${ }^{17}$

In addition to Riksteatern, some other Swedish theatres were also active in inviting guest performances from Finland. As the North Bothnia area had a large Finnishspeaking settlement, the regional theatre of North Bothnia (Norrbottens bygdeteater) hosted tours from Finland, especially by the Kemi and Kajaani City Theatres. Led by Finnish-born Vivica Bandler, the Stockholm City Theatre was active in inviting Finnish theatres to give guest performances from 1970. It turned out that the Finnish-speaking audiences in Sweden were unaccustomed to theatre. ${ }^{18}$ Even the RSKL and other organisations would coordinate theatre tours if they managed to receive target funding from the bilateral Swedish-Finnish Cultural Foundation (founded in 1960) or some private Nordic foundations.

\section{Finnish plays about migration to Sweden}

Although rapid urbanisation transformed Finnish society in the 1960s, the Swedish emigration was not discussed in theatre until the 1970s. The first notable drama depicting the crucial change of rural life in Finland, Jouko Puhakka's Hyvästi Mansikki (1969) premiered at the Joensuu City Theatre as Jouko Turkka's direction and became immensely popular at eastern and northern Finnish theatres. ${ }^{19} \mathrm{Al}$ though the events occur in Finnish countryside, rapidly becoming desolate, some of the characters are young people planning to move to Sweden having heard rumours of the high living standards in the neighbouring country. ${ }^{20}$ In November 1970, the Joensuu production guested at the Stockholm City Theatre and performed in front of an enthusiastic Finnish immigrant audience. ${ }^{21}$ Other productions of the play also visited the Finns in Sweden. ${ }^{22}$

\section{Lauri Sipari: Yrjö Nipanen}

In October 1971, an independent Finnish group theatre KOM launched a tour among the Finns in southern Sweden. Founded by young theatre practitioners in 1969, the KOM Theatre specifically approached socialist and communist organisations. The tour was booked by the National Touring Theatre of Sweden (Riksteatern) which requested the group to create a fresh new play for the occasion. The performance Iltamat ("Soirée") was especially tailored for the local working-class audience and based on documentary material. ${ }^{23}$ Combining songs and poems with a drama performance and concluding with a dance ball among the audience, the performance took its entertaining cabaret form

17 Claes Englund, Världens största teater: Riksteatern 1958-1976 (Stockholm \& Jönköping: Entré, 2003), 224-265.

18 A. P. [Aarno Peltokoski], "Helsingin kaupunginteatteri kävi valloitusmatkalla Tukholmassa," Ruotsinsuomalainen, 3/1970, 26; Jorma Häll, "KOM-teatterin Tukholmanvierailu," Ruotsinsuomalainen, 46/1974, 8.

19 Pentti Paavolainen, Teatteri ja suuri muutto: Ohjelmistot sosiaalisen murroksen osina 1959-1971 (Helsinki: Teatteri, 1992), 191.

20 Jouko Puhakka, "Hyvästi Mansikki," 1969, 70-71, The Manuscript Library of the Theatre Academy (TeaK), Helsinki.

21 Raila Toukola, "Hyvästi Mansikki: Ajankohtainen näytelmä yhteiskunnan muutoksesta," Ruotsinsuomalainen, 18/1970, 9.

22 For instance, Mahlu youth club's amateurs toured with Hyvästi Mansikki in Southern Sweden in February 1972. Ruotsinsuomalainen, 4/1972, 8.

23 The performances took place in Stockholm, Eskilstuna, Örebro, Finnspång, Ludvika, Västerås, Skövde, Trollhättan, Borås and Göteborg. "KOM-teatteri kiertueelle Ruotsiin," Helsingin Sanomat, 26 October 1971, 14; Anneli Ollikainen, "Avantgardea ja aatteen paloa: KOM-teatterin alkuvuodet 1969-1984," in KOM-kirja, eds. Anneli Ollikainen \& Katri Tanskanen (Helsinki: Like, 2013), 48. 
from working-class festival culture in order to discuss migrant issues. ${ }^{24}$ According to a Stockholm critic, the show managed to touch the migrant audience on an emotional level and speak out and illuminate the disadvantages of the migrant labour politics of the time. ${ }^{25}$

The Iltamat performance contained a short play, Yrjö Nipanen, written by Lauri Sipari (b. 1945). The protagonist of the play, Nipanen, is a young Finnish guy without plans for the future. He decides to go and work in Sweden, meets a girl, ends up in various situations and returns to Finland. While Nipanen does not change or grow in the course of the play, the wider socio-political context and moral commentary of his journey is provided by a narrator, interrupting the songs and caricaturelike characters. The tendency to assimilate in Swedish society is ridiculed in the character of a snobbish Finnish woman. One of the characters, a cabinet minister, interrupts the plot with lectures on capitalist economy and labour market: "See Nipanen, we Swedes did not want you here. It is the economy that wants you." According to the cabinet minister, unemployed people from the underdeveloped areas of Europe are pushed to Sweden to do the heavy, monotonous and underpaid work. Hard-working migrants are a good deal for Sweden, "like a ripe fruit from a neighbour's garden". ${ }^{26}$

The KOM Theatre's ensemble combining actors and musicians was exceptional, and many of the songs subsequently became iconic as recordings. Presented in Yrjö Nipanen, the sentimental song Euroopan syrjäkylät ("Hin- terlands of Europe", composed by Kaj Chydenius) summarised the moral of the play. Migration was promoted by the expanding markets and industry. People should consider why we work and make an effort and whether it is the fraternity of capital or nations we should strive for. Although the protagonist, Nipanen, remains indifferent to labour unions, the play ends with a song that stresses the importance of workers' organisation in the attempts to improve working conditions and change the world. ${ }^{27}$

Pekka Milonoff and Tytti Oittinen, seen in the lead roles, had contributed to collecting material for the play. During their studies at the Finnish Theatre School, they had toured in Sweden with the school's own Tikapuuteatteri ("The Ladder Theatre") and used the opportunity to collect migrant guidebooks and meet workers' in their barracks. ${ }^{28}$ Since $Y$ rjö Nipanen on the 1971 tour was a success, the KOM Theatre was booked to continue its tour in Sweden the following spring. At the same time, Yrjö Nipanen was adapted as a radio play. Although the touring venues were inadequate and marketing was insufficient, Yrjö Nipanen and Riksteatern's bookings kept the theatre group going financially during those early years. ${ }^{29}$ As the KOM Theatre continued its frequent visits to Sweden, Yrjö Nipanen remained in the touring repertoire. According to the theatre's musician Eero Ojanen, local audiences had a special connection to the play and sympathised with it. Audience members could even interrupt the performance with their comments as happened once in Stock-

24 Lauri Sipari, "En muista juuri mitään," in KOM-kirja, eds. Anneli Ollikainen \& Katri Tanskanen (Helsinki: Like, 2013), 53-54.

25 Raila Toukola, "KOM-teatterin iltamissa siirtolaisuus esillä mielenkiintoisella tavalla," Ruotsinsuomalainen, 22/1971, 4.

26 Lauri Sipari, "Yrjö Nipanen," 1972, 5, 21, TeaK.

27 Sipari, "Yrjö Nipanen," 6, 24; Sipari, "En muista juuri mitään," 57.

28 Häll, "KOM-teatterin Tukholmanvierailu," 8.

29 Ollikainen, "Avantgardea ja aatteen paloa," 51; Jukka Kajava, "Tiivistystä kaivataan," Helsingin Sanomat, 27 May 1972, 51. 
holm. While Nipanen, in the opening of the play, was reading his friend's letter describing the great conditions of workers in Sweden, an audience member shouted a warning: "Don't believe him! He is lying!"30

Yrjo Nipanen was also staged by the regional Kajaani City Theatre which toured across northern Finland.

\section{Jussi Kylätasku: Matti Väkevä}

Although not performed in Sweden, Jussi Kylätasku's (1943-2002) play Matti Väkevä ("Matti Strong") gathered a wide audience as a radio drama and a stage play in 1972 . Boldly combining the national Kalevala epic, verse and songs with the current social topic and anti-capitalist ethos, Kylätasku's experimental drama or "popular opera" was praised by critics. For them, the play was about traditional mythical Finnishness revolting against modern global windmills, or it was a poetic yet analytical description of workers' exploitation. ${ }^{31}$ A couple of years later, Kylätasku evaluated his own work: "I wrote an operetta that assessed our Kalevala heritage and objected to the EEC. It was accepted as such although the EEC was too big for me to handle. I had a solid world view with its phrases written by history itself." 32

A radio play of Matti Väkevä was directed by Jouko Turkka for the Finnish Broadcasting Company (Yleisradio) in 1972. The musical score was composed by the KOM Theatre's Kaj Chydenius. In December, a stage version premiered at the Theatre School's Tikapuuteatteri in Helsinki. The theatre production was directed by Chydenius' partner Kaisa Korhonen. In 1979, even a television drama was directed by Laura Jäntti. Each of the directors belonged to the radical New Left generation, born in the 1940s.

The protagonist of the play, Matti Väkevä, is a stereotypical hard-working and sincere Finn of mythical and gigantic proportions. Obstinate and individualist, he comes to Sweden and works at the assembly line but refuses to organise with other workers. Taking a walk on the wild side, Matti meets Slussen's colourful characters and becomes a swindler. One of his companions turns out to be the Devil who has been replaced by the modern evil, capitalism.

Searching for capitalism in order to defeat it, Matti and the Devil only find the Banker who guides them to look into production. As the mines of Sweden are already closing, Matti witnesses his fellow worker's suicide while the other migrants are heading for Central Europe in pursuit of better living standards. The Finnish workers have no fatherland. The mysterious capitalism seems to escape: "Its shape keeps on transforming and its plot changing. It has a thousand branches and a million names, but its core and origin are to be found in the darkest corner of the human soul." 33

In the final scene, Matti returns to Finland and loses his temper at the sight of boarding ships. The national riches are taken; people are becoming slaves. Matti kills a policeman, attacks the cranes and dies a beaten man. His fiancé, Aino, regrets: "If only you were given a new life, you would not rage alone. We would march side by side with comrades against the masters' authority and determine the price of

30 Häll, "KOM-teatterin Tukholmanvierailu," 8.

31 Kirsikka Siikala, "Kylätaskun Matti Väkevä eli Suomalainen sankarimyytti hullujussin teräskidassa," Helsingin Sanomat, 8 December 1972, 26; Sole Uexküll, "Näytelmä työvoimasta," Helsingin Sanomat, 10 December 1972, 32; Jukka Kajava, "Palkintojenjako jätti vuoden kuunnelman toiseksi," Helsingin Sanomat, 2 February 1973, 43.

32 Jussi Kylätasku, Revari (Porvoo: WSOY, 1975), 51-52.

33 Jussi Kylätasku, "Matti Väkevä," 1972/1979, 43-50, TeaK. 
human life ourselves. ${ }^{34}$

\section{Pekka Lounela: Ku Ite-Romppanen Ruohtiin läksi ja perreensäki vei}

Titled as 'a play about labour', Pekka Lounela's (1932-2002) Ku Ite-Romppanen Ruohtiin läksi ja perreensäkin vei ("As Romppanen went to Sweden and took his family along") premiered at the small stage of the Tampere Theatre in November 1972. The chairman of the Finnish Dramatists' Association and chief of the Radio Theatre of the national broadcasting company Yleisradio Pekka Lounela was in a key position on the Finnish theatre field. As his brother a Stockholm-based priest and social worker Paavo Lounela was a member of the Finnish immigrant committee, the author was well aware of migrant problems.

In October 1971, at the time when the KOM Theatre was touring Sweden with Iltamat, Pekka Lounela visited Stockholm-based Finns and gave a lecture on Finnish theatre at a local club. Criticising the grim picture of Sweden-Finnish migrants in Finnish television documentaries, the audience - chaired by Osmo Hormia (1926-1983), the professor of Finnish language and culture at Stockholm University - emphasised the need for a permanent Finnish-speaking theatre in Sweden and more tours by Finnish theatres across Sweden. Lounela admitted that the Finnish settlement in Sweden had been ignored in Finnish theatre politics and promised to explore prospective manuscripts by immigrants. ${ }^{35}$

A year later, Lounela was ready to introduce his own migration play to the public. The musical tragicomedy Ku Ite-Romppanen resembled the earlier Finnish migration plays in its fractured Brechtian cabaret form. Each of the plays had satirically depicted national leaders contextualising the individual fates and opening up the macrolevel of the labour market. In Lounela's play, the caricature-like statesmen are named after the then leaders of Finland (Urho Kekkonen), Sweden (King Gustaf VI Adolf) and West Germany (Konrad Adenauer). While the two earlier plays had concentrated on young male workers, Lounela's play described a whole migrant family with eight members. This enabled him to discuss a variety of aspects and social problems regarding the assimilation and lifecycle of immigrants. The rural dialect of the Romppanen family underlined the difficulty of tackling a foreign language, which leads to more severe problems. ${ }^{36}$

Touring regularly among the Finns in North Bothnia, the Kemi City Theatre took Ku Ite-Romppanen in its repertoire in 1973. The play was also staged by the amateur-based Ykspihlaja Workers' Theatre from the harbour district of Kokkola, Finland. In February 1974, the Ykspihlaja Workers' Theatre was invited to give guest performances in Stockholm, Gustavsberg and Södertälje. The tour was organised by the theatre's former member Arvo Latvanen who now worked at the Finnish Society of Stockholm. The author of the play, Lounela, also joined the tour. ${ }^{37}$

Upset about the representation of migrants in the play, professor Hormia strongly criticised the upcoming tour. According to Hormia, Lounela's play was designed to campaign against migration and affect the attitudes back in Finland. Bringing this negative representation of migrant life to the SwedenFinnish settlement was both inappropriate

34 Kylätasku, "Matti Väkevä," 55.

35 M. T. [Manu Teittinen], "Miten käy Suomen teatterielämän?," Ruotsinsuomalainen, 22/1971, 4-5.

36 Pekka Lounela, "Ku Ite-Romppanen Ruohtiin läksi ja perreensäki vei: Näytelmä työvoimasta," 1972, TeaK; Uexküll, "Näytelmä työvoimasta," 32.

37 Allan Laitala, Ykspihlajan Työväen Näyttämö 70 vuotta (Kokkola: Ykspihlajan Työväen Näyttämö, 1977), $19-20$ 
and harmful. In Hormia's reading, the play was a catalogue of cautionary tales as one of the family members gets alienated; another loses her mind; the third one becomes an alcoholic; the fourth gets pregnant with a nonFinnish immigrant, and the fifth one becomes a Swede. ${ }^{38}$

Defending the theatre tour, Latvanen criticised Hormia for his prejudices. As the president of the Sweden-Finnish advocacy organisation (RSKL), was Hormia trying to launch a censorship and decide what is suitable for the Finnish settlement? Did the RSKL consider that it was better for immigrants to have a vapid cultural programme that would leave them indifferent, or would it be preferable to activate the audiences and tease out discussion about the problems of migration? ${ }^{39}$

Lounela also joined the conversation to explain the main points of the play. Having adapted the Brechtian methods of alienation, he did not want the audience to identify with the characters but to make observations. $\mathrm{He}$ was by no means mocking migrants. The only grotesque caricatures in the play were the personifications of the authorities who regulated the labour market. Lounela pointed out: "The forced relocation of labour, according to the demands of the automated, rationalised and economised production, can be seen as the modern Migration Period.”40

\section{The sending country: pessimistic view of the mechanisms and outcomes of migration}

Although empathetic to their migrant protagonists and softened by humour and cabaret songs, the three plays shared a pessimistic view of migration. They examined Finnish migration to Sweden in the wider framework of European economic integration and global migration with millions of guest-workers. Squeezed by historical and structural forces, migrants are seen as passive fools and forced labour in service of the great man-eater, capitalism. Whilst both Yrjö Nipanen and Matti Väkevä end in support of trade unions and the working-class movement, the final song of $K u$ Ite-Romppanen criticises the global market and the future EEC. Although Finnish migration to Sweden was of economic nature, the plays concentrated on pointing out the setbacks in the migrants' quest for a better life. Both Matti Väkevä and Ku Ite-Romppanen can be described as tragedies of migrants on their way down.

As the Stockholm-based social democrat intellectual Seppo Isotalo moved back to Finland in 1973, he was struck by the popularity and nature of the representations of SwedenFinnish guest-workers. According to him, Finnish radio and television were bursting with grim social reports depicting SwedenFinns as alienated alcoholics. The progressive theatres were swarming with offensive migrant caricatures like Yrjö Nipanen, Matti Väkevä and Ite-Romppanen. Isotalo suggested that the denigration of Sweden-Finnish immigrants and their circumstances served in fact as concealed criticism of the EEC. He mocked the leftist theatre practitioners for being careful not to openly criticise President Kekkonen for the drawbacks of capitalism in Finland. Entertaining as they were, these plays failed to communicate with the Sweden-Finnish settlement. According to Isotalo, a housing engineer by occupation, immigrants did not wish to be depicted as 'surplus humans' who live in barracks, stick to the Finnish language and turn down the trade unions. On the contrary, the present-day Finns in Sweden lived in large apartments, learned Swedish and affiliated

38 O. H. [Osmo Hormia], "Synkkää pilaa siirtolaisista," Ruotsinsuomalainen, 9/1974, 5.

39 Arvo Latvanen, "Romppaset - aktivoiva siirtolaisnäytelmä," Ruotsinsuomalainen, 10/1974, 4.

40 Pekka Lounela, ”Romppaset - näytelmä työvoimasta," Ruotsinsuomalainen, 11/1974, 3. 
with the Swedish working-class movement. However, their position remained difficult as long as capitalism was leading the way. ${ }^{41}$

Isotalo's notion of the Euroscepticism in these three plays seems apt. The anti-EEC sentiments were strong across the Nordic countries in the early 1970s. As stated above, after a popular referendum in 1972, Norway turned down the EEC membership. The origins of the grassroot independent theatre movement in Norway was entangled with the anti-EEC movement and the communist youth organisations. New theatre groups sought to cater to working-class and rural audiences. ${ }^{42}$

Although Finland was not to join the EEC, the anti-EEC movement gained support especially among the anti-capitalist rural youth and the radical left. Finland was, after all, to sign its separate trade agreement with the EEC along with the other EFTA countries remaining outside the EEC. Founded in the autumn of 1971, the Finnish anti-EEC committee gathered support from the political youth organisations and especially the radical left. Decisive votes took place in the autumn of 1972 inside the leading government party, the Social Democrats (SDP). A clear majority of the party assembly (83\%), party council $(75 \%)$ and the party committee supported the EEC-agreement despite its "political and economic risks to the small non-aligned countries". ${ }^{3}$

The Euroscepticism of the three playwrights was concretised by the fact that two of them took part in the public anti-EEC movement. Along with an impressive number of cultural workers and intellectuals of the New Left, Jussi Kylätasku and Lauri Sipari (alongside the whole Yrjö Nipanen ensemble) signed the petition for Finland not to ratify the free trade agreement with the EEC. Published on 19 September 1973, the petition highlighted the harmful impact of the EEC agreement on the Finnish-Soviet relations. The trade agreement was regarded as a Trojan Horse that would lead to further restrictions on sovereignty and integration with the West, including the standardisation of legislation and politics. According to the petition, the benefits of Western trade or capitalist market economy were uncertain whereas the new bilateral trade agreements with the Eastern bloc could be based on mutual benefit and would improve employment. Economic competition threatened domestic agriculture and the environment. Aligned with the ethos of the migration plays, the signers of the petition worried about the fate of the underdeveloped areas in eastern and northern Finland, the periphery of Europe, which had nothing but manpower to supply. ${ }^{44}$

For these Finnish theatre dramatists, the EEC question presented a larger conflict between international capitalism and national employees or the machine and man, as the final scene of Matti Väkevä depicted. In the

41 Seppo Isotalo, "Ruotsin siirtotyöläisten kuvaus kiertotie EEC-arvostelulle," Ruotsinsuomalainen, 14/1973, 8.

42 Anna Watson, “'A Good Night Out': When Political Theatre Aims at Being Popular, Or How Norwegian Political Theatre in the 1970s Utilized Populist Ideals and Popular Culture in Their Performances," Nordic Theatre Studies 29, no. 2 (2018): 89-94, https://doi.org/10.7146/nts.v29i2.104615.

43 Tapani Paavonen, Vapaakauppaintegraation kausi: Suomen subde Länsi-Euroopan integraatioon FINN-EFTAsta EC-vapaakauppaan (Helsinki: SKS, 2008), 230-233.

44 “EEC-vapaakauppasopimus torjuttava," Helsingin Sanomat, 19 September 1973, 20. Despite the demonstrations, President Kekkonen signed the trade agreement after having balanced the treaty with similar arrangements with the Eastern Bloc in the autumn of 1973. Paavonen, Vapaakauppaintegraation kausi, 311-317; Juhana Aunesluoma, Vapaakaupan tiellä: Suomen kauppa-ja integraatiopolitiikka maailmansodista EU-aikaan (Helsinki: SKS, 2011), 271-279, 345. 
popular emotional representation, guestworkers were seen as tragic human casualties of capitalism.

Considering the Sweden-Finnish critique towards the plays as a whole, it is evident that the Finnish immigrants to Sweden rejected the negative representation of migrant life produced in Finland, their country of origin. They refused to be seen as guest-workers and preferred to be regarded as settlers. This leads to larger questions of the mechanisms and outcomes of migration. Each of the plays understood migration predicted by a straightforward push-pull dynamics, stressing top-level authorities and larger power structures. However, a more nuanced understanding of migration was on its way, along with new migration policies, acknowledging migrants' own agency and networks. As Castles, De Haas and Miller have stressed, migration processes have their own internal dynamics based on social networks and other feedback mechanisms which leave them undefined by rational policies. They suggest that migration should be seen "as an intrinsic part of the broader processes of development, social transformation and globalisation" which drive migration by increasing the facilities and aspirations to move." ${ }^{35}$

Indeed, although the first migrants to arrive were typically young 'target-earners', starting a family or bringing family members from home tended to create a more permanent and mature settlement. ${ }^{46}$ As for Finnish emigration to Sweden, chain migration based on migrant networks played a considerable role. During her field work in Sweden in the early 1970s, the Finnish sociologist Magdalena Jaakkola noticed that long-term settlers tended to deny the problematic circumstances of migrant communities or at least objected to the public discussion due to a fear of stigmatisation. They had created a Sweden-Finnish double identity. ${ }^{47}$

\section{Settlers: in search for agency and authentic representation}

Since there was a popular demand for positive migrant representations among the Sweden-Finnish settlement, Sweden-Finns were encouraged to strengthen their own cultural agency and produce their own self-representations.

Especially active in this regard was the Finnish Club of the Stockholm Social Democrats. ${ }^{48}$ By 1970 , the social democrats had taken over the Chair of the Central Association of Finnish Societies in Sweden (RSKL). The RSKL had grown rapidly and was now transforming to an advocacy group of SwedenFinnish industrial workers. The new chairman of the RSKL, professor Hormia, stressed social politics and the smooth integration of Finns into Swedish society. ${ }^{49}$ As the majority of the new immigrants were politically inactive rural youth, trade unions paid a lot of attention to their organisation and political mobilisation..$^{50}$

As for cultural needs, according to the social democrats, Sweden-Finnish workers did not want to cherish the traditional national values. Emphasising static 'Finnishness' would prevent them from organising for their rights. They should struggle for equality, collaborate

45 Castles, De Haas \& Miller, Age of Migration, 51.

46 Ibid., 56.

47 Magdalena Jaakkola, Siirtolaiselämää: Tutkimus ruotsinsuomalaisista siirtolaisyhteisönä (Helsinki: University of Helsinki, 1984), 26, 50.

48 In Finnish, Tukholman suomenkielisen sosialidemokraattisen ammattiyhdistysväen kerho.

49 Osmo Hormia, "Suomalaiset Ruotsin yhteiskunnassa," in Ruotsin suomalaiset: Tutkimuksia, puheenvuoroja, kannanottoja (Stockholm: Tiden, 1972), 68-78.

50 Erkki Tammenoksa, "Ruotsinsuomalaisten poliittinen toiminta," in Ruotsin suomalaiset: Tutkimuksia, puheenvuoroja, kannanottoja (Stockholm: Tiden, 1972), 47-67. 
and eventually integrate with the Swedish working class in order to pave a way for a pluralistic multicultural and multilingual Swedish society. It was essential to avoid the proletarisation of Sweden-Finns. Cultural work among migrant workers should be based on a participatory debate with the workers themselves. ${ }^{51}$

These views aligned well with the new migration policy of Sweden in the 1970s. Along with the Netherlands, Canada and Australia, Sweden was adopting a pluralist or multicultural approach to the social organisation of society. ${ }^{52}$ The traditional and new ethnic settlements were to be supported based on their distinctive needs. Criticising the prevalent assimilating policy, sociolinguistic researchers argued that children should be taught in their mother tongue for their first six school years. ${ }^{53}$

Swedish and Finnish sociologists launched several research projects among the SwedenFinnish settlement. The goal of cultural politics was to activate immigrants and increase their participation in society and both Swedish and Finnish culture. In 1974, one of the reports revealed that there was only limited interest in highbrow culture among immigrants. The most attended events were musical entertainment, e.g. comedians' shows and tango and pop concerts. ${ }^{54}$

The RSKL stressed that the cultural activities carried out within the Sweden-Finnish communities were to be defined as workingclass culture since $98 \%$ of its members were industrial workers and their families. The RSKL aspired to plan and control the theatre tours and workshops from Finland in order to ensure the suitability of the programme content and its regional coverage. However, the independent cultural activity of amateur groups and study circles were of key importance. In the autumn of 1973, the RSKL's cultural secretary Manu Teittinen described Sweden-Finnish culture as self-expression that not only depicted the workers but was also based on their own experiences and was shaped, practised and performed by themselves. ${ }^{55}$

The quest for original and unique SwedenFinnish culture was pushed further by the RSKL and the Finnish-speaking broadcasting staff Swedish National Radio (Sveriges Riksradio). In the autumn of 1973, the RSKL set an ambitious goal to create a professional theatre by and for Sweden-Finns. The larger culturopolitical aim was to guide workers to appreciate and create culture of their own. ${ }^{56}$ While the Sweden-Finnish radio launched writing

51 Hormia, "Suomalaiset Ruotsin yhteiskunnassa," 73-76; Isotalo, "Ruotsin siirtotyöläisten kuvaus kiertotie EEC-arvostelulle," 8.

52 Castles, De Haas \& Miller, Age of Migration, 67.

53 Pynnönen, Siirtolaisuuden vanavedessä, 55-58; Nils Erik Hansegård, Kaksikielisiä vai puolikielisiä (Helsinki: SKS, 1979), 95-98.

54 Hannu Huppunen, Allmänkulturell verksamhet för finska invandrare: Rapport frän försöksverksamheten i Västerås 1973/74 (Västerås: Stifts- och landsbibliotek i Västerås, 1974). The importance of music and dance for immigrant identity has been emphasised by Pekka Suutari and Kai Latvalehto. See Pekka Suutari, Götajoen jenkka: Tanssimusiikki ruotsinsuomalaisen identiteetin rakentajana (Helsinki \& Stockholm: Suomen etnomusikologinen seura \& Ruotsinsuomalaisten arkisto, 2000); Kai Latvalehto, "Musiikki ruotsinsuomalaisuuden heijastajana ja toisen sukupolven ihme," in Monta oksaa: Tarinoita ruotsinsuomalaisten elämästä ja kulttuurista 1960-luvulta nykypäivään, eds. Marianne Haapoja \& Saijaleena Rantanen (Valkeakoski: Työväen Musiikkitapahtuma, 2019), 127-141.

55 Manu Teittinen, "Vielä kerran Ruotsinsuomalainen kulttuuri," Ruotsinsuomalainen, 43/1973, 8; "Kulttuuria," Ruotsinsuomalainen, 46/1973, 2.

56 "Kulttuuria," 2. 
competitions in order to find original voices, the RSKL created a regional network of theatre circles and coordinated local workshops.

The number of local Sweden-Finnish journals published by immigrant communities increased rapidly in the early 1970s. The first short story competition in 1973-1974 searched for depictions of migrant life and resulted in 186 texts from over 100 writers. The jury included Hormia, the playwright Esko Korpilinna and the radio journalist behind the initiative, Liisa Paavolainen. In January 1974, Martta Matinlompolo and Kalervo Kujala were declared the winners. ${ }^{57}$

In January 1974, the Finnish theatre circle in Stockholm organised a workshop in order to encourage the group to improvise and produce their own material. Although the drama and music instructors came from Finland, the idea was to make the group materially independent. The director of the theatre circle, Eikku Lahti, explained: "You do not have to call to Finland in order to find plays for the theatre club. Your own group definitely has great ideas that can be developed through improvisation. In this way, the texts about us, the Sweden-Finns, become more truthful. The writers have experienced the incidents themselves and the performers contribute to the production and analyse and adjust the text throughout the process." 58

It was Kalervo Kujala (1927-1998) whose drama texts met the new demands best. The 47-year old storage worker Kujala had moved to Sweden already in 1943 and had previously worked in textile and metal factories. ${ }^{59}$ In April 1974, the Stockholm theatre circle performed his cabaret Suomalaisen kahdet vaatteet ("The
Finn's two sets of clothes"). Describing the double identity of migrants and pinpointing recognisable problems within the settlement, the performance was met with enthusiasm even outside the immigrant community. The production toured in the national SwedenFinnish cultural festival in Örebro (Sweden), in the annual festival of Finnish Expatriates in Kurikka (Finland) and in the national amateur theatre festival in Seinäjoki (Finland). In October 1974, the Stockholm-based SwedenFinnish theatre group was invited as an observer to the international amateur theatre festival Inter-Drama in West Berlin. ${ }^{60}$

During the same year, Kujala finished another one-act play, Valssi tangon tahdissa ("A Valse to the Rhytm of Tango"). Hormia praised how the play, despite its didactic tones, described the Sweden-Finns as rational, active citizens and their local societies as stimulating social hubs. Hormia stressed the importance of breaking the stereotype of the passive and resigned migrant workers and their social and cultural degradation. "Circulating in the Sweden-Finnish communities, there are migration plays describing circumstances from the outsider's point of view." Hormia bid the Sweden-Finnish theatre circles to favour plays that observed migrant reality with a positive migrant outlook. ${ }^{61}$

1975 meant crucial progress for Swedish migration and minority policies which led to the further consolidation of the SwedenFinnish settlement. Immigrants in Sweden were given political citizenship i.e. the right to vote in municipal elections. The Swedish government agreed to fund minority literature and theatre activities from the government

57 Pynnönen, Sirtolaisuuden vanavedessä, 61, 74.

58 The teachers Kaarina Lampinen Jukka Jarvola came through the Finnish Union for Workers' Theatres (TNL).

Eija-Irmeli Lahti, ”Erilainen teatterikurssi," Ruotsinsuomalainen, 7/1974, 4.

59 Pynnönen, Siirtolaisuuden vanavedessä, 117-119.

60 Entries in Ruotsinsuomalainen, 15/1974, 10; 17/1974, 7; 24/1974, 5; 33/1974, 3; 46/1974, 6. Unfortunately

Kujala's original plays were not available.

61 O. H. [Osmo Hormia], "Siirtolaiselämää näytelmänä," Ruotsinsuomalainen, 39/1974, 2. 
culture budget. ${ }^{62}$ In the same year, SwedenFinnish writers founded their own association and the publishing house Finn-Kirja. As the cultural ties to Finland loosened, the cultural ties between Sweden-Finnish and Swedish institutions tightened. Guest-workers had become settlers.

\section{Conclusions}

In the popular emotional representation of the early 1970s Finnish theatre, the migrant worker was seen as a tragic human casualty of inhuman capitalism. The representation was emotionally relevant both to the radical left with its strong anti-capitalist sentiments and to the rural population in northern and eastern Finland that had been hit by structural change and migration. The Finnish plays discussed in the article were all directed by progressiveminded theatre directors and performed either by class-conscious group theatres or northern Finnish theatres. The controversies occurred when the productions were brought to tour in Sweden among the Sweden-Finnish immigrant communities.

The tragic migrant characters and pessimistic understanding of migration, predominant in Finnish theatre, was problematised by the Sweden-Finns. Immigrants did not want to be victimised as exploited guest-workers oppressed by capitalism. This stereotype was created in Finland and was considered to be more connected to Finnish politics and debate on expanding economic integration in Western Europe than the immigrants' own experiences and cultural demand.

As the Sweden-Finnish institutions strengthened in the beginning of the 1970s, active cultural politics sought to increase the immigrants' agency or social capital, their participation and involvement in society, politics and culture. As part of this larger project, it was crucial to replace the negative representation of the passive and resigned guest-worker with a positive image of an active and sociable settler.

Mirroring a larger shift in the more nuanced understanding of migration processes and in Swedish minority politics, the migrant settlement now claimed the right to define and express their own identity and create their own self-representation evolving from community-based cultural activity.

Collaborating with the Swedish labour movement and cherished by the Swedish cultural policy (Kulturradet) from 1975 onwards, the local Sweden-Finnish societies were encouraged to launch spontaneous cultural creation, including collective performances based on their everyday migrant experiences. However, considering this new phase in full will need further study.

\section{Bibliography}

\section{Archival Sources}

National Association of Finns in Sweden (RSKL), Stockholm. The Archive of the Central Association of Finnish Societies in Sweden. Coll. "Kirjeenvaihto ja asiakirjat 1957-1960".

The Manuscript Library of the Theatre Academy (TeaK), Helsinki

Kylätasku, Jussi. ”Matti Väkevä.” 1972/1979.

Lounela, Pekka. "Ku Ite-Romppanen Ruohtiin läksi ja perreensäki vei: Näytelmä työvoimasta." 1972.

Puhakka, Jouko. ”Hyvästi Mansikki." 1969.

Sipari, Lauri. "Yrjö Nipanen." 1972.

\section{Newspaper Articles}

"EEC-vapaakauppasopimus torjuttava." Helsingin Sanomat, 19 September 1973, 20.

"KOM-teatteri kiertueelle Ruotsiin." Helsingin Sano- 
mat, 26 October 1971, 14.

"Kulttuuria." Ruotsinsuomalainen, 46/1973, 2.

O. H. [Hormia, Osmo]. "Synkkää pilaa siirtolaisista." Ruotsinsuomalainen, 9/1974, 5.

O. H. [Hormia, Osmo]. "Siirtolaiselämää näytelmänä." Ruotsinsuomalainen, 39/1974, 2.

Häll, Jorma: "KOM-teatterin Tukholmanvierailu." Ruotsinsuomalainen 46/1974, 8.

Isotalo, Seppo: "Ruotsin siirtotyöläisten kuvaus kiertotie EEC-arvostelulle." Ruotsinsuomalainen 14/ 1973, 8. Originally published in Suomen Sosialidemokraatti, 16 March 1973.

Kajava, Jukka. "Palkintojenjako jätti vuoden kuunnelman toiseksi." Helsingin Sanomat, 2 February 1973, 43.

Kajava, Jukka. ”Tiivistystä kaivataan.” Helsingin Sanomat, 27 May 1972, 51.

Lahti, Eija-Irmeli. "Erilainen teatterikurssi." Ruotsinsuomalainen, 7/1974, 4.

Latvanen, Arvo. "Romppaset - aktivoiva siirtolaisnäytelmä." Ruotsinsuomalainen, 10/1974, 4.

Lounela, Pekka. "Romppaset - näytelmä työvoimasta." Ruotsinsuomalainen, 11/1974, 3.

A. P. [Peltokoski, Aarno]. "Helsingin kaupunginteatteri kävi valloitusmatkalla Tukholmassa." Ruotsinsuomalainen, 3/1970, 26.

Siikala, Kirsikka. "Kylätaskun Matti Väkevä eli Suomalainen sankarimyytti hullujussin teräskidassa." Helsingin Sanomat, 8 December 1972, 26.

M. T. [Teittinen, Manu]. "Miten käy Suomen teatterielämän?” Ruotsinsuomalainen, 22/1971, 4-5.

Teittinen, Manu. "Vielä kerran Ruotsinsuomalainen kulttuuri." Ruotsinsuomalainen, 43/1973, 8.

Toukola, Raila. "Hyvästi Mansikki: Ajankohtainen näytelmä yhteiskunnan muutoksesta." Ruotsinsuomalainen, 18/1970, 9.

Toukola, Raila. "KOM-teatterin iltamissa siirtolaisuus esillä mielenkiintoisella tavalla." Ruotsinsuomalainen, 22/1971, 4.

Uexküll, Sole. "Näytelmä työvoimasta." Helsingin Sanomat, 10 December 1972, 32.

\section{Literature}

Aunesluoma, Juhana. Vapaakaupan tiellä: Suomen kauppa-ja integraatiopolitiikka maailmansodista EU-aikaan. Helsinki: SKS, 2011.

Castles, Stephen, Hein De Haas, \& Mark J. Miller. The Age of Migration: International Population

Movements in the Modern World. 5th ed. London: Palgrave Macmillan, 2014.

Englund, Claes. Världens största teater: Riksteatern
1958-1976. Stockholm \& Jönköping: Entré, 2003.

Finsk teater i Sverige: Suomalainen teatteri Ruotsissa. Stockholm: Statens kulturråd, 1977.

Gröndahl, Satu. "Sweden-Finnish Literature: Generational and Cultural Changes." In Migrants and Literature in Finland and Sweden, edited by Satu Gröndahl \& Eila Rantonen, 37-56. Helsinki: SKS, 2018.

Hansegård, Nils Erik. Kaksikielisiä vai puolikielisiä. Helsinki: SKS, 1979. Originally published as Tvåspråkighet eller halvspråkighet (Stockholm: Aldus/Bonnier, 1968).

Hjerppe, Riitta. Kasvun vuosisata. Helsinki: VAPK, 1990.

Hormia, Osmo, Jaakko Launikari, Paavo Lounela, Martti Pöysälä, \& Erkki Tammenoksa. Ruotsin suomalaiset: Nykyhetki ja tulevaisuus. Porvoo \& Helsinki: WSOY, 1972. Originally published as De finska invandrarnas problem (Stockholm: Prisma, 1971).

Hormia, Osmo. "Suomalaiset Ruotsin yhteiskunnassa." In Ruotsin suomalaiset: Tutkimuksia, puheenvuoroja, kannanottoja, 68-78. Stockholm: Tiden, 1972.

Huppunen, Hannu. Allmänkulturell verksambet för finska invandrare: Rapport frän försöksverksambeten i Västerås 1973/74. Västerås: Stifts- och landsbibliotek i Västerås, 1974.

Jaakkola, Magdalena. Siirtolaiselämää: Tutkimus ruotsinsuomalaisista siirtolaisyhteisönä. Helsinki: University of Helsinki, 1984.

Jokinen, Maijaliisa. "Sverigefinska kultursträvanden." In Finnarnas historia i Sverige. Vol. 3, Tid efter 1945, edited by Jarmo Lainio, 379-423. Jyväskylä: Finnish Historical Society \& Nordiska Museet, 1996.

Koiranen, Vilho A. Suomalaisten siirtolaisten sulautuminen Ruotsissa: Sosiologinen tutkimus Ruotsiin vuosina 1945-1959 muuttaneiden suomenkielisten siirtolaisten kulttuurin muuttumisesta. Porvoo \& Helsinki: WSOY, 1966.

Korkiasaari, Jouni. "Suomalaiset Ruotsissa 1940-luvulta 2000-luvulle". In Suomalaiset Ruotsissa, by Jouni Korkiasaari \& Kari Tarkiainen, 135-496. Turku: Siirtolaisuusinstituutti, 2000.

Kylätasku, Jussi. Revari. Porvoo: WSOY, 1975.

Laitala, Allan. Ykspihlajan Työväen Näyttämö 70 vuotta. Kokkola: Ykspihlajan Työväen Näyttämö, 1977.

Latvalehto, Kai. "Musiikki ruotsinsuomalaisuuden heijastajana ja toisen sukupolven ihme." In Monta oksaa: Tarinoita ruotsinsuomalaisten elämästä ja kulttuurista 1960-luvulta nykypäivään, edited by Marianne Haapoja \& Saijaleena Rantanen, 127141. Valkeakoski: Työväen Musiikkitapahtuma, 
2019.

Lehén-Astala, Laila. "Suomenkielinen teatteri Ruotsissa." In Suomen kieli Ruotsissa, edited by Sulo Huovinen, 1-10. Stockholm: Finn-kirja, 1980.

Ollikainen, Anneli. "Avantgardea ja aatteen paloa: KOM-teatterin alkuvuodet 1969-1984." In KOM-kirja, edited by Anneli Ollikainen \& Katri Tanskanen, 13-266. Helsinki: Like, 2013.

Paavolainen, Pentti. Teatteri ja suuri muutto: Ohjelmistot sosiaalisen murroksen osina 1959-1971. Helsinki: Teatteri, 1992.

Paavonen, Tapani. Vapaakauppaintegraation kausi: Suomen subde Länsi-Euroopan integraatioon FINNEFTAsta EC-vapaakauppaan. Helsinki: SKS, 2008.

Pynnönen, Marja-Liisa. Siirtolaisuuden vanavedessä: Tutkimus ruotsinsuomalaisen kirjallisuuden kentästä vuosina 1956-1988. Helsinki: SKS, 1988.

Rantonen, Eila. "Maahanmuuttajat ja kirjallisuus Suomessa ja Ruotsissa.” In Vähemmistöt ja monikulttuurisuus kirjallisuudessa, edited by Eila Rantonen, 163-191. Tampere: Tampere University Press, 2010 .

Scott, Kirk. The Immigrant Experience: Changing Employment and Income Patterns in Sweden, 19701993. Lund: Lund University Press, 1999.

Seppälä, Mikko-Olavi. Parempi ihminen, parempi maailma: Suomalaisen työväenteatterin päättymätön tarina. Helsinki: Vastapaino, 2020.

Sipari, Lauri. "En muista juuri mitään." In KOM-kir- $j a$, edited by Anneli Ollikainen \& Katri Tanskanen, 51-59. Helsinki: Like, 2013.

Suutari, Pekka. Götajoen jenkka: Tanssimusiikki ruotsinsuomalaisen identiteetin rakentajana. Helsinki \& Stockholm: Suomen etnomusikologinen seura $\&$ Ruotsinsuomalaisten arkisto, 2000.

Tammenoksa, Erkki. "Ruotsinsuomalaisten poliittinen toiminta." In Ruotsin suomalaiset: Tutkimuksia, puheenvuoroja, kannanottoja, 47-67. Stockholm: Tiden, 1972.

Vallenius, Erkki. Kansankodin kuokkavieraat: II maailmansodan jälkeen Ruotsiin muuttaneet suomalaiset kaunokirjallisuuden kuvaamina. Helsinki: SKS, 1998.

Watson, Anna. “'A Good Night Out': When Political Theatre Aims at Being Popular, Or How Norwegian Political Theatre in the 1970s Utilized Populist Ideals and Popular Culture in Their Performances." Nordic Theatre Studies, 29, no. 2 (2018): 87-119. https://doi.org/10.7146/nts.v29i2.104615.

Ylitalo, Hannu. Saatanan suomalainen. Helsinki: Kirjayhtymä, 1971.

Ylärakkola, Arvo. Vertaileva tutkimus Ruotsin Suomalaisseurojen Keskusliiton hallituksen ja hallituksen työvaliokunnan toimenpiteistä vuosina 1970-1977. Handen: RSKL, 1978. 